\title{
Synthesis of hierarchically structured materials: microporous diatoms and nanoporous hydroxyaluminosilicate
}

\author{
D. Höllen $^{1,5}$ (1) D. Klammer ${ }^{1}$ - I. Letofsky-Papst ${ }^{2,3,4} \cdot$ G. Raab $^{1,6} \cdot$ M. Dietzel $^{1}$
}

Received: 12 August 2016/Accepted: 16 September 2016/Published online: 4 October 2016

(c) The Author(s) 2016. This article is published with open access at Springerlink.com

\begin{abstract}
Diatomite is well known to remove particulate matter for a broad range of applications due to diatom skeleton structures. Hydrothermally treated diatomite has been demonstrated to be a feasible pathway to produce advanced materials for the removal of aqueous heavy metal ions. However, single-synthesis routes to obtain altered diatomite for simultaneous removal of dissolved and particulate contaminants are still missing. Therefore, hydrothermal experiments at $\mathrm{pH} 12.8([\mathrm{KOH}]=0.1 \mathrm{M})$, and $T=100^{\circ} \mathrm{C}$ and different added $\mathrm{Al}$ concentrations $(0 \mathrm{mM} \leq[\mathrm{Al}] \leq 11 \mathrm{mM})$ were conducted. Results reveal that in comparison with previous experiments (Höllen et al. in J Mater Sci Eng B 2(10):523-533, 2012) using less alkaline solutions slower dissolution of diatomite is triggering the formation of nanosized spherical particles (NSP) in the presence of diatom skeleton relicts. NSP ranged between 10 and $50 \mathrm{~nm}$ in size and were located within the
\end{abstract}

D. Höllen

daniel.hoellen@unileoben.ac.at

1 Institute of Applied Geosciences, Graz University of Technology, Rechbauerstr. 12, 8010 Graz, Austria

2 Institute of Electron Microscopy and Nanoanalysis (FELMI), Graz University of Technology, Steyrergasse 17, 8010 Graz, Austria

3 Graz Centre for Electron Microscopy (ZFE), Steyrergasse 17, 8010 Graz, Austria

4 Austrian Cooperative Research (ACR), Steyrergasse 17, 8010 Graz, Austria

5 Present Address: Chair of Waste Processing Technology and Waste Management, Montanuniversität Leoben, Franz-JosefStr. 18, 8700 Leoben, Austria

6 Department of Geography, University of Zürich, Winterthurerstr. 190, 8057 Zurich, Switzerland micropores of the diatoms (100-200 nm). TEM-SAED analyses of NSP indicated nanocrystalline phases with distinct lattice planes of 0.45 and $0.26 \mathrm{~nm}$, which could not be attributed to common aluminosilicates. In accordance with the small crystal size, no X-ray diffraction peaks occurred in the bulk reaction product using powder XRD analyses. Metal ion removal experiments at ambient temperature indicated its high removal capacities for aqueous $\mathrm{Cu}^{2+}, \mathrm{Pb}^{2+}$ and $\mathrm{Zn}^{2+}$ ranging from 10 to $99 \%$ (e.g., ion sorption capacities of about $0.02-0.2 \mathrm{mval} / \mathrm{g}$ ). The synthesized product was also successfully tested for its metal ion removal behaviour using a mine drainage solution containing $\mathrm{Cd}^{2+}, \mathrm{Pb}^{2+}, \mathrm{Zn}^{2+}$ and $\mathrm{Sr}^{2+}$. The developed synthesis path yields a hierarchically structured material based on combined micropores (about $100 \mathrm{~nm}$ ) from the diatoms and NSP with nanopores $(1-5 \mathrm{~nm})$ which is promising for large-scale production to simultaneously remove dissolved and particulate contaminants from aqueous solutions.

Keywords Diatomite - Hydrothermal alteration . Nanosized spherical particles $\cdot$ Hierarchically structured material · Heavy metal ion removal

\section{Introduction}

Diatomite is composed of siliceous algae [1] which are widely used for separation of $\mu \mathrm{m}$-sized suspended particles [2] and as substrate for the synthesis of siliceous reaction products, like mordenite [3], analcime, cancrinite and hydroxysodalite [4], for ion removal from aqueous solution. Nevertheless, synthesis routes to obtain tailored hierarchically structured altered diatomite for a 
simultaneous removal of dissolved and particulate contaminants are rare and still challenging with respect to feasibility and cost efficiency.

For instance, a hierarchically structured diatomite/MFItype zeolite composite was produced by using a $\mathrm{NaOH}$ solution for etching the pristine diatomite and adding nanocrystalline silicalite- 1 seeds, which was successfully tested for benzene adsorption [5]. The synthesis of these types of composite materials fits well to similar approaches using various types of templates [6]. An alternative is the synthesis of hollow nanozeolites using organic templates (polydiallyldimethylammonium chloride or polyurea/ polyformaldehyde) which is removed by calcination $[7,8]$. The use of mesoporous silica spheres as template [9] allows abstaining from calcination. Thus, hierarchically structures were successfully synthesized in former studies using synthetic materials like polystyrene or carbon black [10], but limited experiences exist with respect to using naturally occurring materials which offer microsized prestructures for the above approach. A promising material is in particular diatomite from natural deposits which has been used for a long time for filtration (water treatment, beer production, etc.) and is available at low costs and large volumes. In previous studies, hydrothermally treated diatomite yielded mostly zeolites, where experiments without and with seeds (e.g., silicalite nanoparticles) were conducted ([11, 12], respectively). In our former experimental approach [11], we conducted experiments using strong alkaline solutions with or without additional $\mathrm{Al}$ for hydrothermal alteration of diatomite which yielded in the formation of zeolite throughout the formation of an intermediate phase. The latter revealed an extraordinarily high metal ion removal capacity. However, synthesis of a hierarchically structured material containing both micro- and nanopores could not be realized due to fast diatomite dissolution and thus loosing microporous structures.

The aim of the present study is to obtain both micro- and nanopores within a single synthesis and reaction product and to test its suitability for ion removal. For this purpose, an experimental approach for hydrothermal alteration of diatomite using moderate alkaline solutions and a temperature of $100{ }^{\circ} \mathrm{C}$ without using any seed material or template was chosen. The product is characterized with respect to its chemical, mineralogical and micro-/nanostructural characteristics and tested for its ion removal behaviour.

\section{Experimental}

\section{Analytics}

The chemical composition of aqueous solutions was analysed by inductively coupled plasma mass spectroscopy
(ICP-OES; Perkin Elmer Optima 4300) with an accuracy of $\pm 5 \%$ and a precision of $\pm 2 \%$ for $\mathrm{Si}, \mathrm{Al}, \mathrm{K}, \mathrm{Ca}, \mathrm{Mg}, \mathrm{Cd}$, $\mathrm{Cu}, \mathrm{Pb}$ and $\mathrm{Zn}$. ICP-MS (Agilent $7500 \mathrm{cx}$ ) was used for quantification of $\mathrm{Sr}$ and $\mathrm{Cs}$ with an accuracy of about $\pm 10 \%$ and a precision of about $\pm 5 \%$. The $\mathrm{pH}$ was analysed with a precision of \pm 0.03 using WTW Inolab 740 with the $\mathrm{pH}$ electrode BL 26 (Schott) using a three-point calibration ( $\mathrm{pH} \mathrm{4,} 7$ and 10).

Solids were mineralogically characterized by X-ray diffraction pattern (XRD, PANalytical X́Pert Pro; Co K $\alpha$, $40 \mathrm{~mA}, 45 \mathrm{kV}$, sample rotation) between $4^{\circ}$ and $110^{\circ}(2 \theta)$. Secondary electron microscopy images of solids were obtained by scanning electron microscopy (Zeiss DSM 982 Gemini) at an accelerating voltage of $5 \mathrm{kV}$ and working distances between 5 and $10 \mathrm{~mm}$. Therefore, samples were coated with an $\mathrm{Au}-\mathrm{Pd}$ alloy using a Scancoat Six sputter apparatus (Edwards Hochvakuum $\mathrm{GmbH}$ ). Transmission electron microscopy (TEM, FEI Tecnai 12 for TEMSAED, Philipps CM20 for TEM-EDX) was used for chemical and structural characterization at a nanoscale. The specific surface area and related pore size distribution calculations are based on gas adsorption analyses. The specific surface area $(S ; \pm 5 \%)$ was measured by the BET method [13] using a FlowCash II 2300 equipment and a nitrogen-argon mixture. For selected samples, the mesopore radii distribution curve was determined by $\mathrm{BJH}$ method [14] using a Micromeritics TriStar II 3020 V1.03. With this instrument also the micropore volume could be derived from the $t$-plot approach [15].

Hydrogeochemical modelling using PHREEQC with database PhreeqC.dat [16] was used to calculate activities and in the experimental solutions and saturation indices of dissolving (e.g., gibbsite) or possibly precipitating phases. The saturation index is defined as

$S I=\log \frac{\mathrm{IAP}}{K}$,

where IAP stands for the ion activity product and $K$ for the solubility product.

\section{Materials}

Commercially available unconsolidated and untreated natural diatomite (trade Thiele) from a northern African deposit was used for hydrothermal alteration experiments. Experiments were carried out by using two different solutions: Solution A consists of $0.1 \mathrm{M} \mathrm{KOH}$ freshly prepared in a gas-tight $\mathrm{Nalgene}^{\circledR}$ polycarbonate bottle to prevent $\mathrm{CO}_{2}$ adsorption $(\mathrm{pH}=12.9)$. Solution $\mathrm{B}$ was prepared by suspending $1 \mathrm{~g}$ of gibbsite $\left(\gamma-\mathrm{Al}(\mathrm{OH})_{3}\right.$, Merck p.a.) in $0.5 \mathrm{~L}$ of $0.1 \mathrm{M} \mathrm{KOH}$. After a reaction time of 7 days for the dissolution of gibbsite, the reacted solution was separated from the partly remaining gibbsite by 
membrane filtration $(0.45 \mu \mathrm{m})$. The measured $\mathrm{Al}$ concentration of $11 \mathrm{mM}$ represents still undersaturation with respect to gibbsite at the analysed $\mathrm{pH}$ of 12.8 ( $S I_{\text {gibb- }}$ site $=-0.33)$. Due to the increase in the solubility of gibbsite and amorphous aluminium hydroxide (higher soluble compared to gibbsite) with temperature [17], precipitation of $\mathrm{Al}(\mathrm{OH})_{3}$ can be ruled out during heating up to $100{ }^{\circ} \mathrm{C}$.

For cation removal experiments, two different reference solutions were used:

1. A synthetic heavy metal stock solution containing each $0.5 \mathrm{mM}$ of $\mathrm{Cu}^{2+}, \mathrm{Pb}^{2+}$ and $\mathrm{Zn}^{2+}$ which was prepared by dissolving $\mathrm{Pb}\left(\mathrm{NO}_{3}\right)_{2}, \quad \mathrm{Zn}\left(\mathrm{NO}_{3}\right)_{2} \cdot 4 \quad \mathrm{H}_{2} \mathrm{O}$ and $\mathrm{Cu}\left(\mathrm{NO}_{3}\right)_{2} \cdot 3 \mathrm{H}_{2} \mathrm{O}$ (Merck, p.a.) in MilliQ water (pH 5).

2. A mine drainage solution from a carbonate-hosted lead-zinc deposit (Carinthia, Austria). The $0.45 \mu \mathrm{m}$ filtrated stock solution contains $1.250 \mathrm{mM}$ of $\mathrm{Ca}$, $0.00014 \mathrm{mM}$ of $\mathrm{Cd}, 0.026 \mathrm{mM}$ of $\mathrm{K}, 0.665 \mathrm{mM}$ of $\mathrm{Mg}$, $0.153 \mathrm{mM}$ of $\mathrm{Na}, 0.00048 \mathrm{mM}$ of $\mathrm{Pb}, 0.0031 \mathrm{mM}$ of $\mathrm{Si}, 0.00062 \mathrm{mM}$ of $\mathrm{Sr}$ and $0.0017 \mathrm{mM}$ of $\mathrm{Zn}(\mathrm{pH} 8)$.

\section{Experimental setup}

The experimental setup for hydrothermal alteration of diatomite was similar to that in our previous study [11], but differs from it with respect to the molarity of the alkaline solution $(0.1 \mathrm{M}$ instead of $1 \mathrm{M} \mathrm{KOH})$ and by focussing on experiments with an alteration temperature of $100{ }^{\circ} \mathrm{C}$ which turned out to be ideal to produce the intermediate phase in the former experiments [11]. Briefly, for alteration experiments $0.5 \mathrm{~g}$ diatomite reacted with $0.025 \mathrm{~L}$ of experimental solutions $\mathrm{A}$ or $\mathrm{B}$ in a Teflon-coated steel autoclave $(0.1 \mathrm{~L})$ at 25 and $100 \pm 2{ }^{\circ} \mathrm{C}$. After distinct reaction times between 0.25 and 64 days, the autoclaves were cooled down to about $30{ }^{\circ} \mathrm{C}$ and the experimental solutions were immediately separated from the obtained solids by membrane filtration $(0.45 \mu \mathrm{m})$ for solid and liquid analyses. The solids were rinsed with $0.2 \mathrm{~L}$ MilliQ water and dried at $40{ }^{\circ} \mathrm{C}$ before analyses.

The cation removal experiments were carried out by suspending the pristine diatomite material or the reaction products from alteration experiments in the different reference solutions. Therefore, $0.05 \mathrm{~g}$ of the reaction product was suspended in $0.01 \mathrm{~L}$ of (1) the $\mathrm{Cu}^{2+}, \mathrm{Pb}^{2+}$ and $\mathrm{Zn}^{2+}$ containing solution and (2) the mine drainage stock solution. The suspension was placed in a horizontal shaking device (E.B. KS-15) with a frequency of $250 \mathrm{~min}^{-1}$ for up to 3 days at $25^{\circ} \mathrm{C}$. At distinct time intervals, samples were gathered from the solution for analyses.

\section{Results}

\section{Pristine diatomite}

The pristine diatomite in Fig. 1 is composed of diatoms of the Centrales group of mostly disc-shaped form. It consists
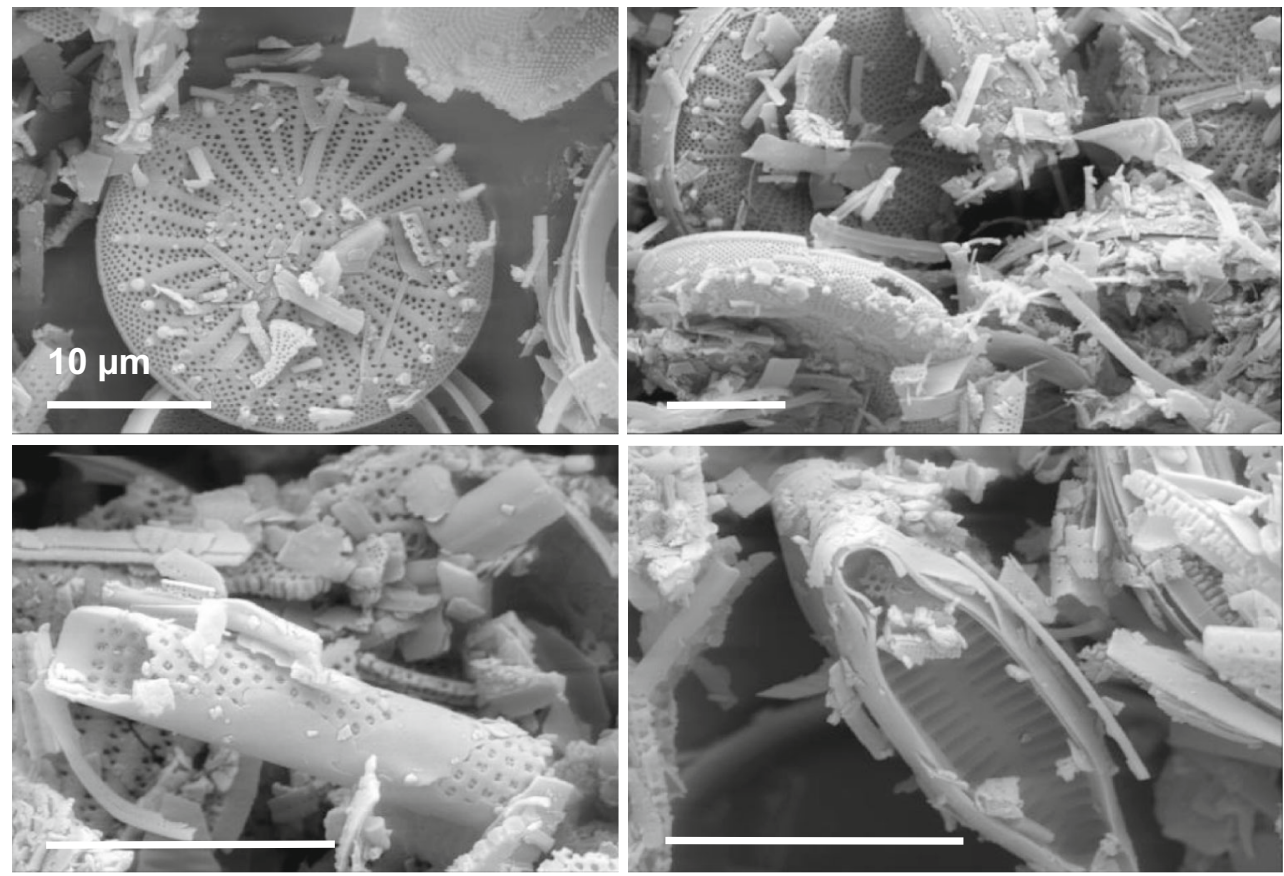

Fig. 1 SEM-SE images of unaltered diatomite showing central and minor amounts of pennate diatoms 
of $97 \%$ opaline silica with an L.O.I. of $3.5 \mathrm{wt} \%$. The specific surface area of the diatomite accounts for $S=15.5$ and $20.1 \mathrm{~m}^{2} \mathrm{~g}^{-1}$ according to the BET and Langmuir

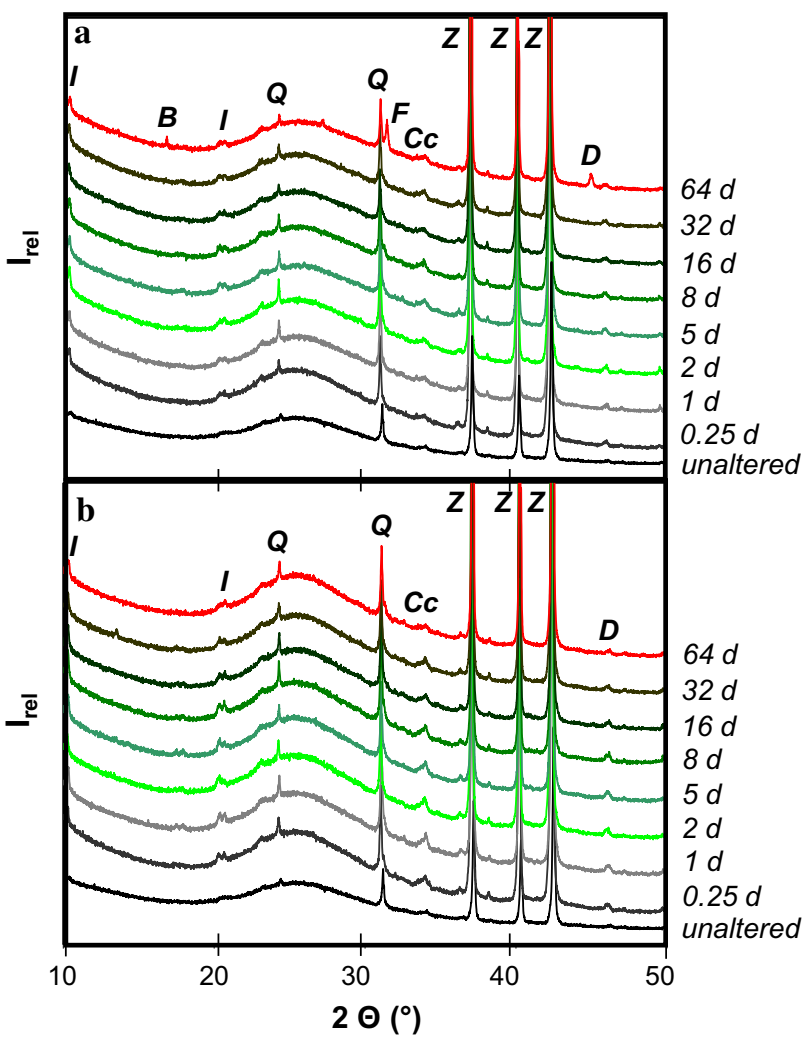

Fig. 2 XRD patterns of alteration products of diatomite in $0.1 \mathrm{M}$ $\mathrm{KOH}$ with (a) and without (b) $0.11 \mathrm{mM}$ Al. I Illite, $Q$ quartz, $C c$ calcite, $Z$ zincite (added as internal standard for the quantification of the amorphous content) method, respectively. Data derived from $t$-plot analyses indicate that $12.2 \mathrm{~m}^{2} \mathrm{~g}^{-1}$ are external surface areas and $3.3 \mathrm{~m}^{2} \mathrm{~g}^{-1}$ micropores. According to BJH adsorption data, $9.3 \mathrm{~m}^{2} \mathrm{~g}^{-1}$ are allotted to a pore diameter range from 1.7 to $300 \mathrm{~nm}$. Values for the average pore diameter range are 13.7 and $20.3 \mathrm{~nm}$ for the BET and BJH method, respectively.

\section{Hydrothermally altered diatomite}

The products from the alteration experiments did not show any X-ray-detectable crystalline phase throughout the whole experimental runs (Fig. 2). However, changing the experimental parameters compared to [11] led to a decrease in the dissolved silica concentration from $261 \pm 23 \mathrm{mM}$ using $1 \mathrm{M} \mathrm{KOH}$ containing $22 \mathrm{mM} \mathrm{Al}$ to $52 \pm 5 \mathrm{mM}$ using $0.1 \mathrm{M} \mathrm{KOH}$ containing $11 \mathrm{mM} \mathrm{Al}$, each after an initial period of 1 day, which correlates to a less alkaline $\mathrm{pH}$ (12.8 for $0.1 \mathrm{M} \mathrm{KOH}, 13.7$ for $1 \mathrm{M} \mathrm{KOH}$ ). A higher dissolved silica concentration was obtained when using pure $0.1 \mathrm{M} \mathrm{KOH}$ which confirms our previous study and is explained by the retarding effect of $\mathrm{Al}$ on silica dissolution [18].

However, TEM-SAED patterns of crystalline particles in diatomite altered for either 1 or 16 days show Bragg reflections representing lattice spacings of 0.45 and $0.26 \mathrm{~nm}$. The absence of crystalline features in XRD patterns can be explained by the small size of the crystals and their low percentage in the overall volume of the sample. Further research is needed to identify the crystalline phase which has formed during our experiments.

SEM imaging clearly indicates a proceeding dissolution of diatoms (Fig. 3). Additionally, the precipitation of the

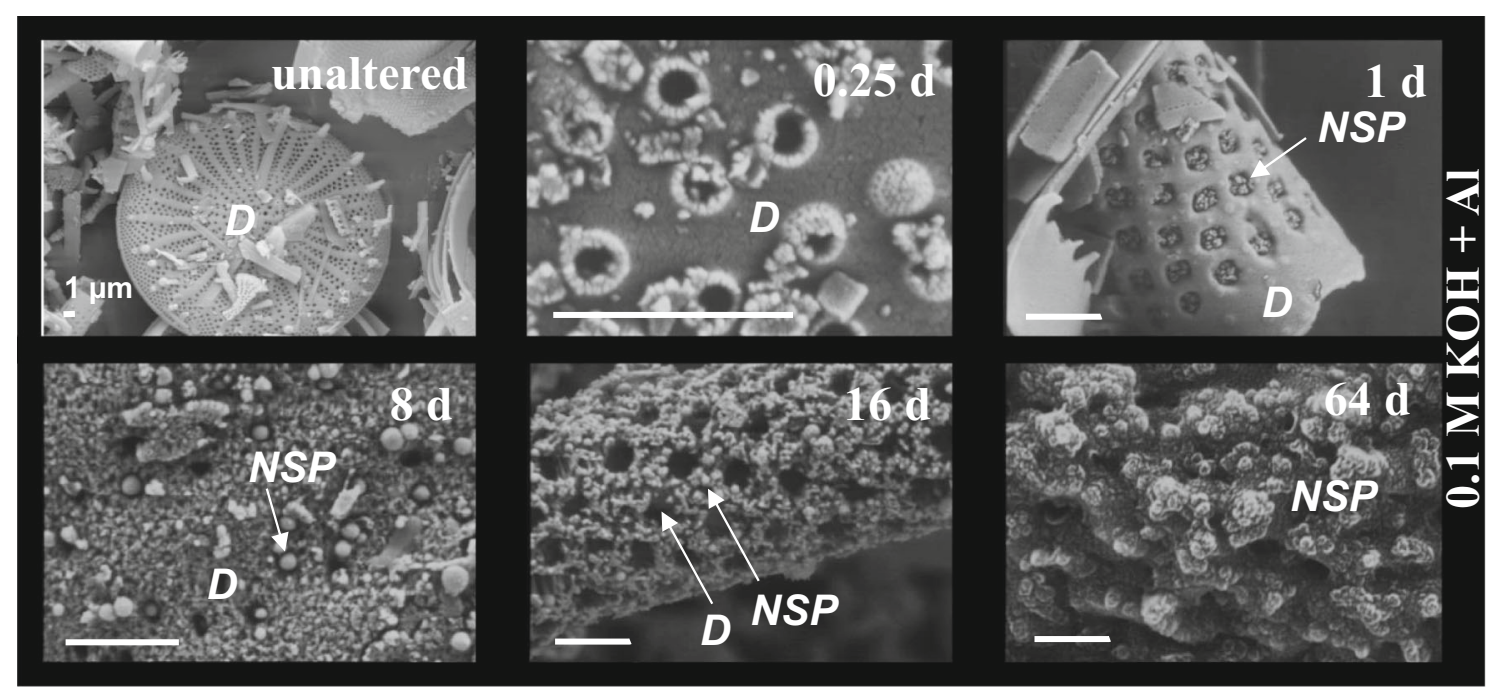

Fig. 3 SEM-SE images of unaltered diatomite and diatomite altered at $100{ }^{\circ} \mathrm{C}$ for various reaction times in $0.1 \mathrm{M} \mathrm{KOH}$ containing $11 \mathrm{mM}$ of Al. $D$ diatom, NSP nanosized spherical particles 


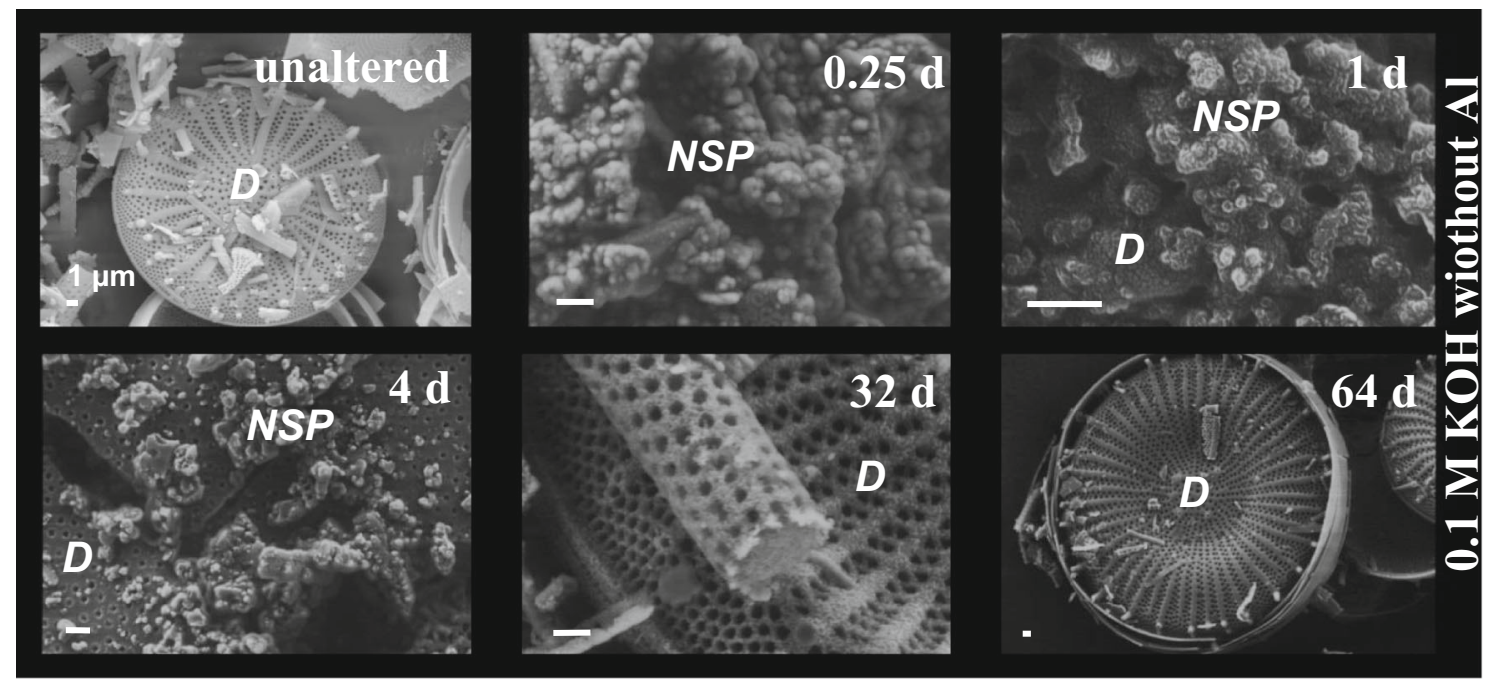

Fig. 4 SEM-SE images of unaltered diatomite and diatomite altered at $100{ }^{\circ} \mathrm{C}$ for various reaction times in $0.1 \mathrm{M} \mathrm{KOH}$ without added $\mathrm{Al}$. $D$ diatom, NSP nanosized spherical particles

spherical-shaped particles with a diameter of $100 \mathrm{~nm}$ takes place. These particles were formed directly in the pores and at the surfaces of the diatoms. The formation of these particles occurs in several steps: SEM-SE images indicate already after 0.25 days in experiments with $11 \mathrm{mM} \mathrm{Al}$ bulges around the pores of the diatoms. Subsequently, a hierarchically structured material is formed which is composed of these particles in the pores of the diatoms and the diatoms themselves. Later on the spherical particles cover the whole surface of the diatoms, but are not visible within the pores any more. Finally, the surface of the diatoms becomes rougher and remains covered with the particles (Fig. 3).

Using experimental solution A, without dissolved $\mathrm{Al}$, irregularly shaped isometric particles with a diameter of some $100 \mathrm{~nm}$ are formed already after 0.25 day (Fig. 4). After 1 day, the material looks similar as after 64 days in the experiments with $\mathrm{Al}$ (Fig. 3). This stage might again be described as hierarchically structured material. The particles start to disappear afterwards and are absent after 32 day.

The specific surface area of diatomite increases from $S=15.5-25.4 \mathrm{~m}^{2} \mathrm{~g}^{-1}$ during the 8 days of hydrothermal alteration at $100{ }^{\circ} \mathrm{C}$ in $0.1 \mathrm{M} \mathrm{KOH}$ (experimental solution B). The pore size distribution sum curve (Fig. 5; Table 1) shows that the relative amount of small pores increases with ongoing alteration in $0.1 \mathrm{M} \mathrm{KOH}$, which can be expressed by a decrease in the median pore diameter from 9 to $4 \mathrm{~nm}$ within 8 days. On the other hand, the higher relative percentage of larger pores indicates the survival of diatoms. Additional data from a previous study [11] using $1 \mathrm{M} \mathrm{KOH}$ are also displayed in Fig. 5 and show a

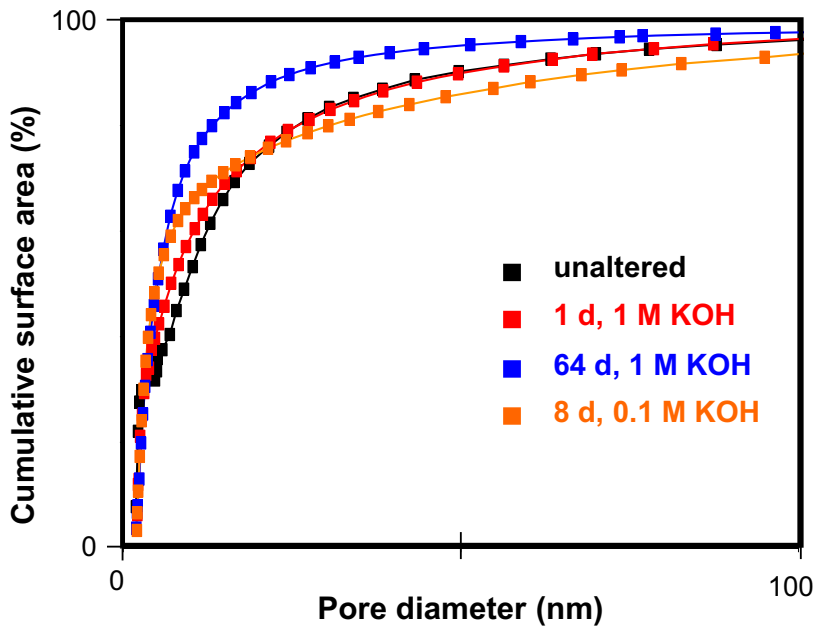

Fig. 5 Cumulative pore surface area (\%) of unaltered diatomite and diatomite altered 8 days in $0.1 \mathrm{M} \mathrm{KOH}$ with $11 \mathrm{mM} \mathrm{Al}$ (this study) and for 1 and 64 days in $1 \mathrm{M} \mathrm{KOH}$ with $22 \mathrm{mM} \mathrm{Al}$ at $100{ }^{\circ} \mathrm{C}$ [11] as a function of pore diameter analysed by the $t$-plot method by BET

comparable increase in the cumulative pore surface area for pores $<10 \mathrm{~nm}$, but a decrease for pores $>10 \mathrm{~nm}$.

In Fig. 6, representative TEM-EDX spectra of amorphous and crystalline pore fillings in altered diatomite are shown. TEM analyses of diatomite altered for 1 day in $0.1 \mathrm{M} \mathrm{KOH}$ containing $\mathrm{Al}$ indicate that the diatoms themselves remain amorphous, but pore fillings are formed which are partially crystalline and enriched in $\mathrm{Al}$ compared to the diatoms. Some of these pore fillings contain significant amounts of potassium. Generally, crystalline pore fillings are richer in $\mathrm{Al}$ and $\mathrm{K}$ than amorphous ones. Some non-spherical particles are randomly oriented, whereas 
Table 1 Incremental pore surface area $\left(\mathrm{m}^{2} / \mathrm{g}\right)$ of unaltered diatomite and diatomite altered 8 days in $0.1 \mathrm{M} \mathrm{KOH}$ with $11 \mathrm{mM} \mathrm{Al}$ (this study) and for 1 and 64 days in $1 \mathrm{M} \mathrm{KOH}$ with $22 \mathrm{mM} \mathrm{Al}$ at $100{ }^{\circ} \mathrm{C}$ [11] as a function of pore diameter analysed by the $t$-plot method by BET

\begin{tabular}{lllcl}
\hline $\begin{array}{l}\text { Pore range } \\
\text { diameter }(\mathrm{nm})\end{array}$ & $\begin{array}{l}\text { Unaltered } \\
\text { diatomite } \\
\left(\mathrm{m}^{2} / \mathrm{g}\right)\end{array}$ & $\begin{array}{l}\text { Diatomite altered } 8 \text { days in } 0.1 \mathrm{M} \\
\mathrm{KOH} \text { with } 11 \mathrm{mM} \mathrm{Al}\left(\mathrm{m}^{2} / \mathrm{g}\right)\end{array}$ & $\begin{array}{l}\text { Diatomite altered 1 day } \\
\text { in } 1 \mathrm{M} \mathrm{KOH} \text { with } \\
22 \mathrm{mM} \mathrm{Al}\left(\mathrm{m}^{2} / \mathrm{g}\right)\end{array}$ & $\begin{array}{l}\text { Diatomite altered 64 days } \\
\text { in } 1 \mathrm{M} \mathrm{KOH} \mathrm{with} \mathrm{22} \mathrm{mM} \\
\mathrm{Al}\left(\mathrm{m}^{2} / \mathrm{g}\right)\end{array}$ \\
\hline $2-10$ & 4.91 & 14.81 & 14.72 & 17.75 \\
$10-20$ & 2.10 & 2.10 & 4.37 & 3.22 \\
$20-30$ & 0.67 & 1.13 & 1.56 & 1.13 \\
$30-40$ & 0.41 & 0.80 & 1.11 & 0.54 \\
$40-50$ & 0.26 & 0.60 & 0.71 & 0.31 \\
$50-60$ & 0.17 & 0.51 & 0.51 & 0.20 \\
$60-70$ & 0.15 & 0.39 & 0.42 & 0.15 \\
$70-80$ & 0.10 & 0.32 & 0.27 & 0.12 \\
$80-90$ & 0.08 & 0.24 & 0.24 & 0.08 \\
$90-100$ & 0.07 & 0.25 & 0.19 & 0.06 \\
$>100$ & 0.36 & 1.47 & 0.91 & 0.56 \\
\hline
\end{tabular}

Fig. 6 Comparison of characteristic TEM-EDX spectra of amorphous and crystalline pore fillings in altered diatomite

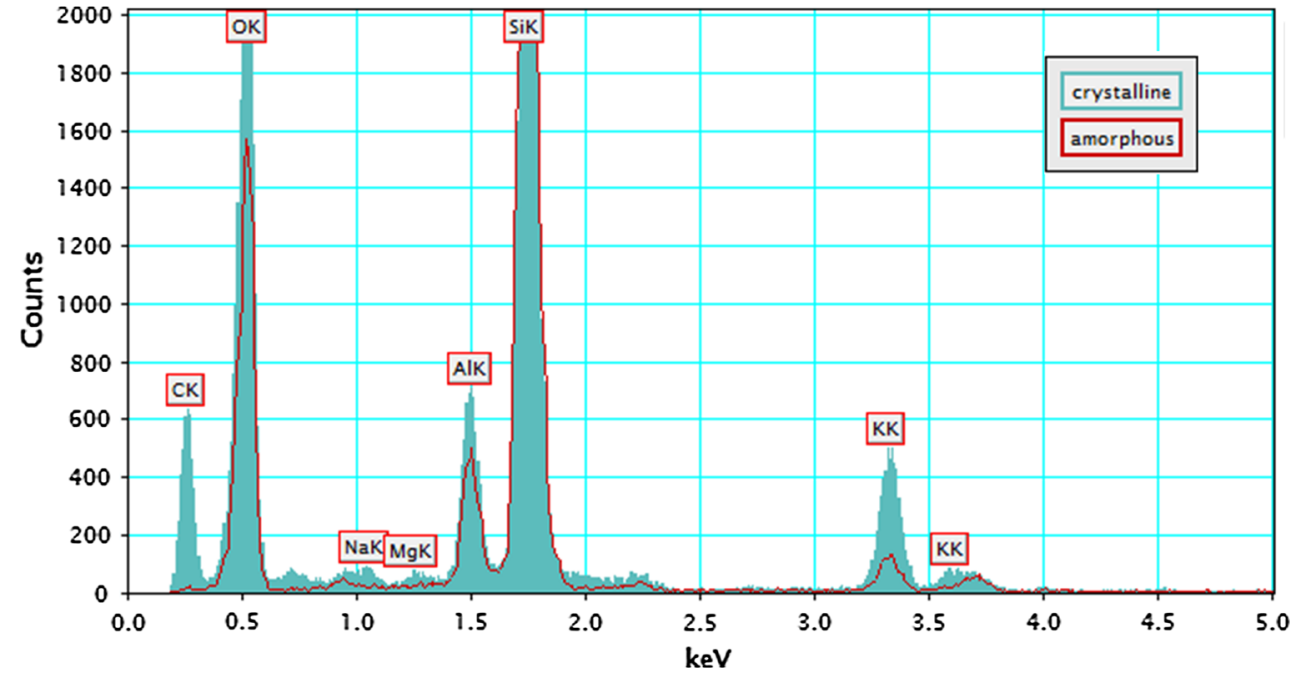

others show a preferred orientation. Those particles with a preferred orientation are enriched in $\mathrm{Si}$ and $\mathrm{Al}$, whereas the randomly oriented particles are enriched in $\mathrm{K}$ and $\mathrm{Ca}$.

After 16 days in $0.1 \mathrm{M} \mathrm{KOH}$ containing $11 \mathrm{mM} \mathrm{Al}$, amorphous spherical particles occur which coexist with irregularly shaped, partly crystalline particles (Fig. 7) known from less altered diatomite (1 day). The spherical particles become enriched with respect to $\mathrm{K}$ and $\mathrm{Al}$ with increasing size. Crystalline non-spherical particles contain more $\mathrm{K}$ and $\mathrm{Al}$ than amorphous particles of the same shape. Consequently, increase in structural ordering is associated with an increase in $\mathrm{K}$ and $\mathrm{Al}$ concentration. Crystalline non-spherical particles are richer in $\mathrm{K}$ and poorer in $\mathrm{Al}$ compared to spherical, amorphous particles. However, the $\mathrm{K}$ content of spherical amorphous particles varies a lot. The Al concentration in crystalline particles is lower than that in large spherical amorphous particles. A comparison between the chemical composition of pure diatoms and diatoms covered with particles clearly indicates that the particles are enriched in $\mathrm{Al}, \mathrm{Ca}$ and $\mathrm{K}$.

\section{Metal removal experiments}

In Fig. 8, the dissolved concentrations of $\mathrm{Pb}, \mathrm{Cu}$ and $\mathrm{Zn}$ after metal removal experiments are presented as fractions of their initial concentration in the synthetic heavy metal solution which accounted for about $0.5 \mathrm{mM}$. Obviously, unaltered diatomite has only a limited capacity to remove heavy metal ions from the synthetic solution containing $\mathrm{Cu}$, $\mathrm{Pb}$ and $\mathrm{Zn}$ ions. $\mathrm{Pb}$ ion removal is insignificant, and $\mathrm{Cu}$ removal accounts for less than $20 \%$. Alteration of diatomite in $0.1 \mathrm{M} \mathrm{KOH}$ creates a capacity to remove $\mathrm{Pb}$ ions from the synthetic $\mathrm{Cu}-\mathrm{Pb}-\mathrm{Zn}$ solution. $\mathrm{Pb}$ ion removal is more efficient (up to $99 \%$ ) when $11 \mathrm{mM} \mathrm{Al}$ is present. In the 
Fig. 7 Characteristic TEM image of crystalline nanoparticles in the pores of altered diatoms (left) and evaluation of SAED patterns of the respective particle (right)




Fig. 8 Heavy metal ion removal from the synthetic $\mathrm{Cu}-\mathrm{Pb}-\mathrm{Zn}$ solution (each $0.5 \mathrm{mM} \mathrm{Cu}, \mathrm{Pb}$ and $\mathrm{Zn}, \mathrm{pH} \mathrm{5}$ ) after 3 days of reaction with unaltered diatomite $\left(t_{\mathrm{syn}}=0\right.$ day) and diatomite altered for various durations ( 0.25 day $\leq t_{\text {syn }} \leq 64$ days) in $0.1 \mathrm{M} \mathrm{KOH}$ with or without $11 \mathrm{mM} \mathrm{Al}$ (a and $\mathbf{b}$, respectively). Concentrations of dissolved metal ions are given as ratios between the final concentration, $c_{\mathrm{f}}$, and the initial concentration, $c_{\mathrm{i}}$

absence of $\mathrm{Al}$, it only accounts for $40-70 \%$ with a maximum for diatomite altered for intermediate periods (4 days). Similarly, the capacity for removal of $\mathrm{Cu}$ ions increases during alteration of diatomite from $20 \%$ for unaltered diatomite to $40 \%$ during alteration in pure $0.1 \mathrm{M} \mathrm{KOH}$ and even to $60 \%$ in the presence of $\mathrm{Al}$. Compared to $\mathrm{Cu}$ and $\mathrm{Pb}$, $\mathrm{Zn}$ ions are only removed to a very limited degree $(10-20 \%)$ from the synthetic $\mathrm{Cu}-\mathrm{Pb}-\mathrm{Zn}$ solution even by altered diatomite. The order of selectivity of heavy metal ion removal from the synthetic solution is therefore $\mathrm{Pb}>\mathrm{Cu}>\mathrm{Zn}$, no matter if $\mathrm{Al}$ has been present in alteration experiments. Like in our previous study [11], heavy metal removal was associated with release of $\mathrm{K}$ from the solid into the solution. Correspondingly, to the lower heavy metal removal also the $\mathrm{K}$ release was with resulting dissolved concentrations of $1.4 \pm 0.1$ and $0.6 \pm 0.1 \mathrm{mM}$ for Al-containing and $\mathrm{Al}-$ free alteration experiments, respectively, only about one-third of the value obtained previously for alteration productions synthesized using $1 \mathrm{M} \mathrm{KOH}$.

In contrast to the experiments with the synthetic solution containing $\mathrm{Cu}, \mathrm{Pb}$ and $\mathrm{Zn}$ ions, unaltered diatomite removes $94 \%$ of $\mathrm{Pb}$ ions and more than $50 \%$ of $\mathrm{Zn}$ ions from the mine drainage solution ( $\mathrm{pH}$ 8) (Fig. 9). Also $\mathrm{Cd}$ concentrations could be reduced by $36 \%$ to $0.009 \mu \mathrm{mol} \mathrm{L}{ }^{-1}$. Alteration products remove heavy metal ions from the mine drainage solution more efficiently than unaltered diatomite. Like for all other alteration products, heavy metal ion removal is connected with $\mathrm{K}$ release. The relative amount of heavy metal ions removed by altered diatomite is higher for the mine drainage solution than for the synthetic solution containing $\mathrm{Cu}, \mathrm{Pb}$ and $\mathrm{Zn}$ ions which had much higher initial concentrations. Interestingly, diatomite altered in pure $0.1 \mathrm{M} \mathrm{KOH}$ was more capable of removing heavy metals than diatomite altered in Al-containing $0.1 \mathrm{M} \mathrm{KOH}$. $\mathrm{Zn}$ ions are removed more efficiently than $\mathrm{Pb}$ ions from the mine drainage solution, although $\mathrm{Pb}$ ions are removed more efficiently than $\mathrm{Zn}$ ions from the synthetic solution containing $\mathrm{Cu}, \mathrm{Pb}$ and $\mathrm{Zn}$ ions. The capacity of $\mathrm{Cd}$ ion removal is between that of $\mathrm{Pb}$ and $\mathrm{Zn}$ ion removal. Generally, the duration of alteration had no impact on the capacity of heavy metal removal. Water 




Fig. 9 Heavy metal removal from a mine drainage solution $\left(0.14 \mu \mathrm{mol} \mathrm{L}{ }^{-1} \mathrm{Cd}, 0.48 \mu \mathrm{mol} \mathrm{L}{ }^{-1} \mathrm{~Pb}, 17 \mu \mathrm{mol} \mathrm{L}{ }^{-1} \mathrm{Zn}, \mathrm{pH} 8\right)$ after 3 days of reaction with unaltered diatomite $\left(t_{\mathrm{syn}}=0\right.$ day) and diatomite altered for various durations $\left(0.25\right.$ day $\leq t_{\mathrm{syn}} \leq 64$ days $)$ in $0.1 \mathrm{M} \mathrm{KOH}$ with or without $11 \mathrm{mM}$ aqueous $\mathrm{Al}$ (a and $\mathbf{b}$, respectively). Concentrations of dissolved metal ions are given as ratios between the final concentration, $c_{\mathrm{f}}$, and the initial concentration, $c_{\mathrm{i}}$

hardness in terms of $\mathrm{Ca}$ and $\mathrm{Mg}$ concentration was also significantly reduced by altered diatomite, especially when $\mathrm{Al}$ had been present in alteration experiments. Diatomite dissolution during metal ion removal experiments as expressed by concentrations of dissolved $\mathrm{Si}$ is slightly higher when alteration had taken place in presence of Al.

\section{Discussion}

\section{Diatomite alteration experiments}

In the diatomite alteration experiments, a hierarchically structured material has been formed. A comparison with previous experiments using $1 \mathrm{M} \mathrm{KOH} \mathrm{[11],} \mathrm{where}$ $70-80 \mathrm{wt} \%$ of the added diatomite were dissolved, shows not only slower dissolution kinetics, but also a lower thermodynamic solubility at lower $\mathrm{KOH}$ molarity. This is in agreement with a similar study on hydrothermal dissolution of diatomite due to replacement of Si by Al [19]. In our previous study [11], we observed the formation of an intermediate aluminosilicate phase and finally of the zeolites merlinoite and chabazite. By decreasing the molarity of the alkaline solution from 1 to $0.1 \mathrm{M}$, we addressed the problem of contemporaneousness versus subsequence of the observed processes of diatomite dissolution and formation of new phases and achieved several effects:

1. We decreased diatomite dissolution and let the micropores survive, which yields a hierarchically structured microporous-nanoporous material and allows simultaneous removal of particulate and dissolved matter from aqueous solutions.

2. We completely prevented the formation of zeolites which were very selective but less efficient for heavy metal removal than their amorphous precursors.

3. We produced irregularly shaped particles growing in the micropores of diatoms (Fig. 1). These particles did not yield any peaks of crystalline phases in XRD patterns. However, TEM-SAED patterns reveal that some of these particles are amorphous whereas others are crystalline with $d$ values of 0.45 and $0.26 \mathrm{~nm}$ (Fig. 7). This cannot be explained by a different degree of order, but rather by the small particle size and low percentage of these particles in the sample. TEM-EDX analyses indicate that the chemistry of these particles is similar to that of the intermediate phase in our previous study [11] although they do not act as precursor for zeolite formation in our current experiments. Pore size distribution curves (Fig. 5) indicate that hydrothermal alteration of diatomite using $0.1 \mathrm{M} \mathrm{KOH}$ increases both the nanopore $(<5 \mathrm{~nm})$ and the micropore (about $100 \mathrm{~nm}$ ) volume.

Combining the similarity in chemistry and morphology of the observed pore fillings with the intermediate phase mentioned in our previous study [11] with the bimodal pore size distribution allows addressing a hierarchically structured material containing nanosized spherical particles (NSP). The finding of this NSP-containing material is a main outcome of the present study. This material combines micropores of the diatoms with a diameter of about $100 \mathrm{~nm}$ with nanopores of the NSP in the range of less than $5 \mathrm{~nm}$ according to BJH (Fig. 5). Such hierarchically structured materials are highly promising for technical applications [20]. For example, they might be used for filtration issues removing suspended matter down to $100 \mathrm{~nm}$ by the diatom micropores and dissolved ions in the range of few $\mathrm{nm}$ by the nanopores of the NSP. For this purpose, it is of great 
benefit that the NSP is formed in the pores of the diatoms. This suggests a connectivity of the nanopores of the former with the micropores of the latter which enhances the catalytic activity [6].

Intermediate phases during zeolite formation have been described from experiments without diatoms, e.g., an amorphous phase containing four-membered rings was described [21]. In our previous study [11], we discussed in detail the different $\mathrm{Si} / \mathrm{Al}$ ratio in hydroxyl-alumino-silicate (HAS) phases. In the present study, measured $\mathrm{Si} / \mathrm{Al}$ ratios of the NSP are generally higher and $\mathrm{K}$ concentrations lower, but are only semi-quantified due to the influence of the diatoms underneath. However, also the NSP produced in this study seem to be of similar chemical composition as the HAS phases observed previously [11]. In contrast to [11], we found some NSP already to be crystalline which is with respect to size $(100 \mathrm{~nm})$ and shape (isometric) similar to another study [22], but our observed $d$ values do neither correspond to those of zeolite $\mathrm{P}$ which was observed back then nor to merlinoite which formed later on in our previous experiments [11]. Thus, additional research is needed to identify the crystalline phase occurring in the NSP. In summary, controlled less-intense dissolution level of diatomite results in precipitation of NSP within still partly remaining diatom skeletons.

\section{Metal removal experiments}

Diatomite altered in alkaline solutions can remove heavy metals from aqueous solutions. Contrarily, it was shown that the capacity of the unaltered diatomite to remove $\mathrm{Pb}$ ions from aqueous solution at $\mathrm{pH} 5$ is lacking [11], but relevant at higher $\mathrm{pH}$ [23] using diatomite with a similar specific surface area and pore size distribution. The alteration products containing the NSP exhibit a classic ion exchange behaviour defined as metal ion removal with simultaneous $\mathrm{K}$ release. This is in agreement with its $\mathrm{K}$ content and with other studies showing that in hydrothermal syntheses of various zeolites alkali metals are already present in an amorphous precursor phase [11,24].

The presence or absence of $\mathrm{Al}$ in alteration experiments has a strong impact on the performance of the alteration products in metal ion removal experiments (Fig. 8, 9; Tables 2, 3, 4, 5). When Al was present in alteration

Table 2 Heavy metal ion removal from the synthetic $\mathrm{Cu}-\mathrm{Pb}-\mathrm{Zn}$ solution $\left(\mathrm{pH}\right.$ 5) after 3 days of reaction with unaltered diatomite $\left(t_{\mathrm{syn}}=0\right.$ day) and diatomite altered for various durations $\left(0.25\right.$ day $\leq t_{\text {syn }} \leq 64$ days $)$ in $0.1 \mathrm{M} \mathrm{KOH}$ with $11 \mathrm{mM}$ aqueous $\mathrm{Al}$

\begin{tabular}{|c|c|c|c|c|c|c|}
\hline$\overline{t_{\text {syn }} \text { (days) }}$ & $\mathrm{Cu}\left(\mu \mathrm{mol} \mathrm{L}{ }^{-1}\right)$ & $\mathrm{Pb}\left(\mu \mathrm{mol} \mathrm{L}{ }^{-1}\right)$ & $\mathrm{Zn}\left(\mu \mathrm{mol} \mathrm{L}{ }^{-1}\right)$ & $\mathrm{Si}\left(\mu \mathrm{mol} \mathrm{L}{ }^{-1}\right)$ & $\mathrm{Al}\left(\mu \mathrm{mol} \mathrm{L}{ }^{-1}\right)$ & $\mathrm{K}\left(\mu \mathrm{mol} \mathrm{L}{ }^{-1}\right)$ \\
\hline 0 & 417 & 510 & 485 & n.a. & n.a. & n.a. \\
\hline 0.25 & 238 & 36 & 368 & 132 & 2.48 & 1241 \\
\hline 1 & 223 & 8 & 362 & 133 & 3.57 & 1336 \\
\hline 2 & 210 & 11 & 369 & 138 & 14.91 & 1421 \\
\hline 4 & 203 & 9 & 368 & 140 & 1.10 & 1422 \\
\hline 8 & 183 & 4 & 382 & 149 & 0.72 & 1519 \\
\hline 16 & 170 & 3 & 382 & 128 & 0.91 & 1533 \\
\hline 32 & 260 & 10 & 409 & 119 & 1.60 & 1285 \\
\hline 64 & 241 & 8 & 404 & 125 & 5.64 & 1290 \\
\hline
\end{tabular}

Concentrations of dissolved metal ions are given as ratios between the final concentration, $c_{\mathrm{f}}$, and the initial concentration, $c_{\mathrm{i}}$

Table 3 Heavy metal ion removal from the synthetic $\mathrm{Cu}-\mathrm{Pb}-\mathrm{Zn}$ solution $\left(\mathrm{pH}\right.$ 5) after 3 days of reaction with unaltered diatomite $\left(t_{\mathrm{syn}}=0\right.$ day) and diatomite altered for various durations $\left(0.25\right.$ day $\leq t_{\text {syn }} \leq 64$ days $)$ in $0.1 \mathrm{M} \mathrm{KOH}$ without added $\mathrm{Al}$

\begin{tabular}{|c|c|c|c|c|c|c|}
\hline$t_{\text {syn }}$ (days) & $\mathrm{Cu}\left(\mu \mathrm{mol} \mathrm{L}{ }^{-1}\right)$ & $\mathrm{Pb}\left(\mu \mathrm{mol} \mathrm{L}{ }^{-1}\right)$ & $\mathrm{Zn}\left(\mu \mathrm{mol} \mathrm{L}{ }^{-1}\right)$ & $\mathrm{Si}\left(\mu \mathrm{mol} \mathrm{L}{ }^{-1}\right)$ & $\mathrm{Al}\left(\mu \mathrm{mol} \mathrm{L}{ }^{-1}\right)$ & $\mathrm{K}\left(\mu \mathrm{mol} \mathrm{L}{ }^{-1}\right)$ \\
\hline 0 & 417 & 510 & 485 & n.a. & n.a. & n.a. \\
\hline 0.25 & 331 & 209 & 429 & 159 & 19.49 & 525 \\
\hline 1 & 326 & 206 & 413 & 189 & 17.35 & 500 \\
\hline 2 & 339 & 205 & 435 & 146 & 2.35 & 548 \\
\hline 4 & 288 & 144 & 418 & 182 & 0.83 & 729 \\
\hline 8 & 292 & 164 & 428 & 156 & 1.17 & 743 \\
\hline 16 & 309 & 188 & 444 & 161 & 0.40 & 733 \\
\hline 32 & 315 & 237 & 447 & 155 & 1.16 & 592 \\
\hline 64 & 311 & 318 & 431 & 177 & 3.27 & 497 \\
\hline
\end{tabular}

Concentrations of dissolved metal ions are given as ratios between the final concentration, $c_{\mathrm{f}}$, and the initial concentration, $c_{\mathrm{i}}$ 
Table 4 Heavy metal removal from a mine drainage solution $(\mathrm{pH} 8)$ after 3 days of reaction with unaltered diatomite $\left(t_{\mathrm{syn}}=0\right.$ day) and diatomite altered for various durations $\left(0.25\right.$ day $\leq t_{\text {syn }} \leq 64$ days $)$ in $0.1 \mathrm{M} \mathrm{KOH}$ with $11 \mathrm{mM}$ aqueous Al

\begin{tabular}{|c|c|c|c|c|c|c|c|c|c|}
\hline $\begin{array}{l}t_{\text {syn }} \\
\text { (days) }\end{array}$ & $\begin{array}{l}\mathrm{Ca} \\
\left(\mu \mathrm{mol} \mathrm{L}{ }^{-1}\right)\end{array}$ & $\begin{array}{l}\mathrm{K} \\
\left(\mu \mathrm{mol} \mathrm{L}{ }^{-1}\right)\end{array}$ & $\begin{array}{l}\mathrm{Mg} \\
(\mu \mathrm{mol} \mathrm{L} \\
-1)\end{array}$ & $\begin{array}{l}\mathrm{Na} \\
\left(\mu \mathrm{mol} \mathrm{L} \mathrm{L}^{-1}\right)\end{array}$ & 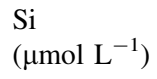 & $\begin{array}{l}\mathrm{Cd} \\
\left(\mu \mathrm{mol} \mathrm{L} \mathrm{L}^{-1}\right)\end{array}$ & $\begin{array}{l}\mathrm{Pb} \\
\left(\mu \mathrm{mol} \mathrm{L}{ }^{-1}\right)\end{array}$ & $\begin{array}{l}\mathrm{Sr} \\
\left(\mu \mathrm{mol} \mathrm{L}{ }^{-1}\right)\end{array}$ & $\begin{array}{l}\mathrm{Zn} \\
\left(\mu \mathrm{mol} \mathrm{L}{ }^{-1}\right)\end{array}$ \\
\hline 0 & 1406 & 92 & 742 & 216 & 129 & 0.009 & 0.029 & $<0.009$ & 7.67 \\
\hline 0.25 & 779 & 848 & 515 & 140 & 100 & 0.001 & 0.192 & 0.49 & 0.14 \\
\hline 1 & 612 & 930 & 475 & 129 & 241 & 0.001 & 0.055 & 0.40 & 0.34 \\
\hline 2 & 616 & 874 & 492 & 120 & 198 & 0.001 & 0.112 & 0.36 & 0.19 \\
\hline 4 & 628 & 894 & 491 & 116 & 236 & 0.002 & 0.013 & 0.42 & 0.09 \\
\hline 8 & 601 & 924 & 467 & 112 & 279 & 0.002 & 0.036 & 0.47 & 0.33 \\
\hline 16 & 597 & 1008 & 495 & 120 & 318 & 0.002 & 0.049 & 0.53 & 0.35 \\
\hline 32 & 659 & 696 & 504 & 120 & 230 & 0.002 & 0.018 & 0.46 & 0.17 \\
\hline 64 & 676 & 812 & 481 & 123 & 263 & 0.002 & 0.218 & 0.46 & 0.36 \\
\hline
\end{tabular}

Concentrations of dissolved metal ions are given as ratios between the final concentration, $c_{\mathrm{f}}$, and the initial concentration, $c_{\mathrm{i}}$

Table 5 Heavy metal removal from a mine drainage solution $\left(0.14 \mu \mathrm{mol} \mathrm{L}{ }^{-1} \mathrm{Cd}, 0.48 \mu \mathrm{mol} \mathrm{L}{ }^{-1} \mathrm{~Pb}, 17 \mu \mathrm{mol} \mathrm{L}{ }^{-1} \mathrm{Zn}, \mathrm{pH}\right.$ 8) after 3 days of reaction with unaltered diatomite $\left(t_{\text {syn }}=0\right.$ day $)$ and

\begin{tabular}{|c|c|c|c|c|c|c|c|c|c|}
\hline $\begin{array}{l}t_{\mathrm{syn}} \\
\text { (days) }\end{array}$ & $\begin{array}{l}\mathrm{Ca} \\
\left(\mu \mathrm{mol} \mathrm{L}{ }^{-1}\right)\end{array}$ & $\begin{array}{l}\mathrm{K} \\
\left(\mu \mathrm{mol} \mathrm{L}{ }^{-1}\right)\end{array}$ &  & 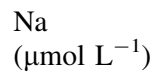 & $\left.\begin{array}{l}\mathrm{Si} \\
(\mu \mathrm{mol} \mathrm{L} \\
-1\end{array}\right)$ & $\begin{array}{l}\mathrm{Cd} \\
\left(\mu \mathrm{mol} \mathrm{L}{ }^{-1}\right)\end{array}$ & $\begin{array}{l}\mathrm{Pb} \\
\left(\mu \mathrm{mol} \mathrm{L}{ }^{-1}\right)\end{array}$ & $\begin{array}{l}\mathrm{Sr} \\
\left(\mu \mathrm{mol} \mathrm{L} \mathrm{L}^{-1}\right)\end{array}$ & $\left.\begin{array}{l}\mathrm{Zn} \\
(\mu \mathrm{mol} \mathrm{L} \\
-1\end{array}\right)$ \\
\hline 0 & 1406 & 92 & 742 & 216 & 129 & 0.0090 & 0.029 & $<0.009$ & 7.67 \\
\hline 0.25 & 784 & 413 & 531 & 172 & 177 & 0.0006 & 0.012 & 1.31 & 0.08 \\
\hline 1 & 811 & 318 & 533 & 150 & 174 & 0.0007 & 0.007 & 1.28 & 0.08 \\
\hline 2 & 775 & 326 & 524 & 146 & 201 & 0.0007 & 0.005 & 1.11 & 0.07 \\
\hline 4 & 724 & 419 & 495 & 141 & 217 & 0.0008 & 0.029 & 0.96 & 0.09 \\
\hline 8 & 703 & 481 & 520 & 135 & 214 & 0.0007 & 0.018 & 1.01 & 0.10 \\
\hline 16 & 732 & 479 & 527 & 132 & 212 & 0.0004 & 0.013 & 1.05 & 0.06 \\
\hline 32 & 740 & 400 & 519 & 128 & 209 & 0.0005 & 0.013 & 1.09 & 0.08 \\
\hline 64 & 800 & 298 & 508 & 122 & 237 & 0.0005 & 0.028 & 1.27 & 0.14 \\
\hline
\end{tabular}

Concentrations of dissolved metal ions are given as ratios between the final concentration, $c_{\mathrm{f}}$, and the initial concentration, $c_{\mathrm{i}}$

experiments, the $\mathrm{Pb}$ ion removal capacity is much higher than for alteration products from experiments without $\mathrm{Al}$. This is by far not as pronounced for $\mathrm{Cu}$ and $\mathrm{Zn}$ ions. Considering that the NSP are formed more pronounced and are more stable in the presence of $\mathrm{Al}$, it can be concluded that the NSP are responsible for preferential $\mathrm{Pb}$ ion removal. This might be explained by a crystalline order of the NSP, which is consistent with TEM-SAED patterns. $\mathrm{Cu}$ and $\mathrm{Zn}$ ions fit worse into the cavities of these nanocrystals. Hence, the limited fixation of $\mathrm{Cu}$ and $\mathrm{Zn}$ ions by diatomite altered with $0.1 \mathrm{M} \mathrm{KOH}$ can be explained predominantly by ion adsorption. The fact that the more efficient $\mathrm{Pb}$ ion fixation by alteration products from experiments with $\mathrm{Al}$ correlates with a twice as high release of $\mathrm{K}$ supports the suggestion that ion exchange in a cage-like structure takes place, although the Bragg reflections in TEM-SAED patterns could not yet be assigned to a specific crystalline phase. diatomite altered for various durations $\left(0.25\right.$ day $\leq t_{\text {syn }} \leq 64$ days $)$ in $0.1 \mathrm{M} \mathrm{KOH}$ without added $\mathrm{Al}$ 
metal ion removal capacity is mostly due to the increased surface area. Contrarily, the presence of $\mathrm{Al}$ in alteration experiment has an effect, since diatomite altered in pure $0.1 \mathrm{M} \mathrm{KOH}$ was more capable of removing $\mathrm{Cd}, \mathrm{Pb}$ and $\mathrm{Zn}$ ions than diatomite altered in Al-containing $\mathrm{KOH}$ (Fig. 8). This means that the NSP, which are more "metastable" in presence of $\mathrm{Al}$, performed very well for highly contaminated solutions like the synthetic solution containing $\mathrm{Cu}$, $\mathrm{Pb}$ and $\mathrm{Zn}$ ions, but decrease metal removal capacities at low metal concentrations like for the used mine drainage solution. It is suggested that adsorption sites of the NSP favour heavy metal ion removal at high metal concentrations but act reversely at low concentrations, whereas the adsorption sites on the diatoms behave vice versa due to their different ion affinities.

The heavy metal removal capacity of altered diatomite is in agreement with our previous study [11], in which we found out that moderately altered diatomite containing the intermediate phase was very effective, but less selective for the removal of $\mathrm{Cu}, \mathrm{Pb}$ and $\mathrm{Zn}$ from synthetic and natural aqueous solutions than intensely altered diatomite containing zeolites. Unfortunately, the NSP-containing material produced in the present study stays far behind both the alteration products obtained in our previous study [11], which contained the intermediate phase and zeolites, with respect to effectivity and selectivity. This can be explained by the fact that the largest percentage of the material applied for metal removal experiments consists still of diatoms, whereas they dissolved more intense in our previous experiments. Consequently, further action is needed to increase the relative percentage of the NSP in the hierarchically structured material.

\section{Conclusions}

Hydrothermal alteration of naturally occurring diatomite in alkaline solution can lead to the formation of crystalline aluminosilicates which has been demonstrated in several studies $[11,20,22,26]$. Comparingly low molarity of the alkaline solutions used for the present hydrothermal alteration of diatomite suppresses the formation of crystalline aluminosilicates. The herein obtained synthesized product is composed of nanosized spherical particles (NSP) which are partly nanocrystalline and nanoporous and are formed before the complete dissolution of diatoms directly in their microporous skeletons. This enables the application of this tailored material for simultaneous removal of suspended and dissolved contaminants, e.g., in wastewater treatment. Considering the relatively low $\mathrm{KOH}$ molarity $(0.1 \mathrm{M})$ of the synthesis solution and the less reaction time required for synthesis (1 day), an economically beneficial technology of diatomite alteration, e.g., by activating packed columns of diatomite by alkaline solutions will be developed in ongoing studies. Challenging issues for ongoing and future studies comprise of the increase in the relative percentage of the NSP in the hierarchically structured material to adjust distinct metal removal efficiencies without dissolving the diatoms completely to maintain significant microporosity for removal of suspended contaminants.

Acknowledgments Open access funding provided by [Montanuniversität Leoben]. The authors thank Patrick Grunert for support of SEM analyses, Michael Piller for BET measurements, Maria Hierz and Andrea Wolf (NAWI Graz Central Lab for Water, Minerals and Rocks) for support in performing the experiments and Roland Pomberger for supporting this study.

\section{Compliance with ethical standards}

Conflict of interest The authors declare that they have no conflict of interest.

Open Access This article is distributed under the terms of the Creative Commons Attribution 4.0 International License (http://crea tivecommons.org/licenses/by/4.0/), which permits unrestricted use, distribution, and reproduction in any medium, provided you give appropriate credit to the original author(s) and the source, provide a link to the Creative Commons license, and indicate if changes were made.

\section{References}

1. Smol J, Eugene F (2010) The diatoms: applications for the environmental and earth sciences. Cambridge University Press, Cambridge

2. Parkinson J, Gordon R (1999) Beyond micromachining: the potential of diatoms. Trends Biotechnol 17(5):190-196

3. Sanhueza V, Kelm U, Cid R (2003) Synthesis of mordenite from diatomite: a case study of zeolite synthesis from natural material. J Chem Technol Biotechnol 78:485-488

4. Chaisena A, Rangsriwatananon K (2005) Synthesis of sodium zeolites from natural and modified diatomite. Mater Lett 59:1474-1479

5. Yu W, Yuan P, Liu D, Deng L, Yuan W, Tao B, Cheng H, Chen F (2015) Facile preparation of hierarchically porous diatomite/MFI type zeolite composites and their performance of benzene adsorption: the effects of $\mathrm{NaOH}$ etching pretreatment. J Hazard Mater 285:173-181

6. Chen LH, Li XY, Rooke Y, Zhang YH, Yang XY, Tang Y, Xiao FS, Su BL (2012) Hierarchically structured zeolites: synthesis, mass transport properties and applications. J Mater Chem 22:17381-17403

7. Wang X, Wang W, Tang Y, Wang Y, Fu S, Gao Z (2000) Fabrication of hollow zeolite spheres. Chem Commun 21:2161-2162

8. Kang Y, Shan W, Wu J, Zhang Y, Wang X, Yang W, Tang Y (2006) Uniform nanozeolite microspheres with large secondary pore architecture. Chem Mater 18(7):1861-1866

9. Dong A, Wang Y, Tang Y, Ren N, Zhang Y, Gao Z (2002) Hollow zeolite capsules: a novel approach for fabrication and guest encapsulation. Chem Mater 14(8):3217-3219

10. Chu N, Wang J, Zhang Y, Yang J, Lu J, Yin D (2010) Nestlike hollow hierarchically MCM-22 microspheres: synthesis and exceptional catalytic properties. Chem Mater 22:2757-2763 
11. Höllen D, Klammer D, Letofsky-Papst I, Dietzel M (2012) Hydrothermal alteration of diatomite for removal of aqueous $\mathrm{Cu}^{2+}, \mathrm{Pb}^{2+}$ and $\mathrm{Zn}^{2+}$. J Mater Sci Eng B 2(10):523-533

12. Anderson M, Holmes S, Hanif N, Cundy C (2000) Hierarchical pore structures through diatom zeolitization. Angew Chem Int Ed 39:2707-2710

13. Brunauer S, Emmett P, Teller E (1938) Adsorption of gases in multimolecular layers. J Am Chem Soc 60:309-319

14. Barrett E, Joyner L, Halenda P (1951) The determination of pore volume and area distributions in porous substances. I. Computations from nitrogen isotherms. J Am Chem Soc 73:373-380

15. Lippens B, de Boer J (1965) Studies on pore systems in catalysts: V. The $t$ method. J Catal 4:319-323

16. Parkhurst D, Apello C (1999) User's guide to PHREEQC (V2). Geological Survey, Denver

17. Hitch B, Mesmer R, Baes J, Sweeton F (1980) The solubility of gibbsite $\left(\alpha-\mathrm{Al}(\mathrm{OH})_{3}\right)$ in 1 molal $\mathrm{NaCl}$ as a function of $\mathrm{pH}$ and temperature. Oak Ridge National Laboratory, Oak Ridge

18. Iler R (1979) The chemistry of silica: solubility, polymerization, colloid and surface properties and biochemistry of silica. Wiley, Chichester

19. Dixit S, van Cappellen P, van Bennekom A (2001) Processes controlling solubility of biogenic silica and pore water build-up of silicic acid in marine sediments. Mar Chem 73:333-352
20. Anderson M, Holmes S, Mann R, Foran P, Cundy C (2005) Zeolitisation of diatoms. J Nanosci Nanotechnol 5:92-95

21. Li P, Liu L, Xiong G (2011) Effect of zeolite precursor on the formation of MCM-41 molecular sieve containing zeolite $\mathrm{Y}$ building units. Phys Chem Chem Phys 13:11248-11253

22. Du Y, Shi S, Dai H (2011) Water-bathing synthesis of highsurface-area zeolite P from diatomite. Particuology 9:174-178

23. Sheng G, Wang S, Hu J, Lu Y, Li J, Dong Y, Wang X (2009) Adsorption of $\mathrm{Pb}(\mathrm{II})$ on diatomite as affected via aqueous solution chemistry and temperature. Colloid Surf A 339:159-166

24. Wakihara T, Kohara S, Sankar S, Saito S, Sanchez-Sanchez M, Overweg R, Fan W, Ogura M, Okubo T (2006) A new approach to the determination of atomic architecture of amorphous zeolite precursors by high-energy X-ray diffraction technique. Phys Chem Chem Phys 8:224-227

25. Safa M, Larouci M, Meddah B, Valemens P (2012) The sorption of lead, cadmium, copper and zinc ions from aqueous solutions on a raw diatomite from Algeria. Water Sci Technol 65:1729-1737

26. Wang Y, Tang Y, Wang X, Dong G, Shan Z, Gao Z (2001) Fabrication of hierarchically structured zeolites through layer-bylayer assembly of zeolite nanocrystals on diatom templates. Chem Lett 30:118-119 